\title{
Jak (ne)vysvětlit českou bezbožnost? Analytická sociologie jako inspirace pro sociologii náboženství ${ }^{1}$
}

\author{
Roman Vido ${ }^{2}$ \\ Sociologický ústav AV ČR v.v.i. Jilská 1, 11000 Praha

\begin{abstract}
How (Not) to Explain Czech Irreligiousness? Analytical Sociology as Inspiration for the Sociology of Religion. In the last two decades, the sociology of religion in Czechia has produced a great deal of empirical analyses of Czech religiosity, revealing a high level of irreligion and distrust to (traditional) religious institutions in the Czech society. However, most of them lack in explaining the identified phenomena and do not go beyond the level of description and/or historicization. As suggested by the author, Czech sociology of religion has been in short supply of theory that might help to achieve a deeper understanding of the factors that lie behind the observed tendencies. The paper suggests that analytical sociology, with its central concept of social mechanisms, can be viewed as one of possible remedy for the perceived deficit.

Sociológia 2019, Vol. 51 (No. 4: 420-443)

https://doi.org/10.31577/sociologia.2019.51.4.19
\end{abstract}

Key words: Czech Republic; irreligion; sociology of religion; theory; analytical sociology; social mechanisms; socialization

\section{Úvod}

Uplynulé dva roky se setkaly s velkými očekáváními u všech, kdo se profesně zabývají analýzou kvantitativních dat týkajících se religiozity. V roce 2017 totiž proběhla další vlna empirického šetření projektu European Values Study (EVS), který zahrnuje také část věnovanou problematice náboženství. O rok později se pak uskutečnilo další dotazníkové šetření v rámci International Social Survey Programme (ISSP) s modulem Náboženství. Badatelská obec tak má k dispozici nové soubory empirických dat, jež mohou přispět k prohloubení sociologického vhledu do náboženské situace v současných evropských společnostech.

Bude napínavé sledovat, zdali tento prríslib dojde svého naplnění v kontextu studia religiozity v české společnosti. Navzdory čtvrtstoletí fungování obnovené české sociologie náboženství lze totiž konstatovat, že hlubšího porozumění náboženské situaci v české společnosti, která bývá odbornou i laickou veřejností vnímána jako „specifická“ či „výjimečná“, se sociologické obci stále nedostává. Primární problém přitom nepředstavuje nedostatek empirických dat - přinejmenším v prrípadě dat kvantitativních je na čem stavět. Pocitovaný deficit se vztahuje ke schopnosti české sociologie náboženství překročit rovinu

\footnotetext{
1 Tato stat’ vznikla v rámci projektu CSDA Research - Výzkumný program Českého sociálněvědního datového archivu: Česká republika v Mezinárodním programu sociálnich šetření ISSP, výzkum kvality dat a zdrojů dat řešeném na Sociologickém ústavu AV ČR v.v.i.

2 Korespondence: PhDr. Roman Vido, Ph.D., Sociologický ústav AV ČR v.v.i., Jilská 1, 11000 Praha 1, Česká republika. E-mail: roman.vido@soc.cas.cz
} 
popisu a historického ukotvení „české výjimečnosti“ a nabídnout přesvědčivé sociologické vysvětlení zdejší vysoké míry „bezbožnosti“ a nedůvěry k (tradičnímu) institucionalizovanému náboženství.

V předkládané stati se snažím neuspokojivý stav dosavadního sociologického zkoumání české (non)religiozity doložit a současně identifikovat zdroj, který leží u jeho kořenů. $\mathrm{V}$ dalším kroku pak představuji jeden ze směrů sociologického bádání, kterým je možné se při jeho řešení vydat. Na podkladu kritické reflexe tří reprezentativních českých publikací ze sociologie náboženství v ní poukazuji na nedostatečnou práci se sociologickou teorií. V logické návaznosti na ni pak nastiňuji základní principy analytické sociologie a její explanační možnosti pro studium současné české (ne)náboženské reality.

\section{K čemu je teorie?}

Miloslav Petrusek se ve své stati o „návratu (sociologické) teorie do Čech“ přihlásil $\mathrm{k}$ požadavkům na dobrou vědu, které svého času formuloval americký sociolog Randal Collins: totiž $\mathrm{k}$ její sdělnosti a nesamozřejmosti jí sdělovaného. Současně na adresu části (nejen) české sociologické produkce kriticky poznamenal, že tyto požadavky „téměř programové nesplňuje“ (Petrusek 2011: 1024). V souvislosti s empiricky orientovanou sociologií pak upozornil na riziko „deštníkové sociologie“, již míní sociologickou praxi, v níž bývá k záplavě empirických dat přidávána $a d$ hoc teorie. Takový postup dle Petruska neumožňuje naplnění jednoho z Collinsových požadavků: totiž sdělovat něco jiného, než co již dávno víme.

Taktéž Miloš Havelka (2010) volal v téže době po větším zapojení teorie do sociologického zkoumání české společnosti: „Absence teorií a inspirativních interpretací soudobých sociálních procesů je dnes ve svém celku bud' nahrazována jednostranným, v zásadě pozitivistickým zdůrazňováním významu deskripce datových souborů, př́ípadně převyprávěním pramenů, anebo kompenzována přimknutím k nejrůznějším politickým doktrínám“ (Havelka 2010: 86). Soudobý sociologický ,mainstream“ podle Havelky vykazuje nepřehlédnutelný deficit, který se projevuje např́íklad přetrvávající absencí obecnější a testovatelné teorie postkomunistických společností.

Jakkoliv mohou dané výroky vyznívat dramaticky, nemají v úmyslu nadměrně generalizovat. Petrusek tak s nadějí konstatuje, že poslední pětiletí je u nás ,poměrně bohaté na sociologickou literaturu (...) dosti výrazně teoreticky orientovanou, často myšlenkově inspirativní a namnoze inovativní tam, kde se to před časem prŕliš neočekávalo“ (Petrusek 2011: 1023) a že „,návrat k sociologické teorii, at' už jí budeme rozumět více méně - v rámci dosavadních konvencí - cokoliv, je nevratný“ (tamtéž: 1030). Také Havelka (2010: 85) nechce, ,jednostranně tvrdit (...), že zajímavé teoretické pokusy a konceptuálně podnětné interpretace nových sociálních fenoménů v soudobé české sociologii 
neexistují vůbec“, ale spíše vystihnout obecnější tendenci, která české sociálněvědní prostředí provází.

Vrátíme-li se k předmětu této stati, můžeme se v návaznosti na diskutované téma ptát, do jaké míry se dané „obecnější tendence“ odrážejí v české sociologii náboženství. Nebo jinak řečeno: do jaké míry je u nás v této sociologické disciplíně využíváno sociologické teorie $\mathrm{k}$ nastolování a řešení netriviálních sociologických otázek.

\section{(Ne)př́tomnost teorie v české sociologii náboženství}

V závěru přehledové studie o empirických výzkumech religiozity v České republice po roce 1989 konstatuje Jan Váně (2012), že tuzemská sociologie $\mathrm{v}$ současnosti disponuje dostatečným množstvím datových souborů z oblasti náboženství. Zároveň dodává, že „česká sociologie náboženství nemá ani tak problém se získáváním a dostatečným počtem empirických sociologických dat jako s konceptualizací těchto dat a s aplikací (zejména kvalitativních) metod“ (Váně 2012: 376). Kriticky hodnotí také nedostatečnou provázanost kvantitativních a kvalitativních výzkumů. Dle jeho mínění je tím umenšena možnost hlubšího porozumění „tvrdým“ datům z kvantitativních šetření, resp. jejich „důvěryhodná korekce“ a „zpřesňující interpretace“ prostřednictvím kvalitativních výzkumných postupů.

Na uvedeném hodnocení zaujme takřka úplná absence zmínky o teoretické složce sociologického zkoumání. Vyjma nepř́iliš jasné formulace o „konceptualizaci dat" se Váněho resumé zaměřuje čistě na rovinu výzkumných metod. Jakkoliv je to u studie zaměřené na empirické výzkumy pochopitelné, přesto je dané mlčení v něčem příznačné: neprímo totiž zpřítomňuje Petruskovo varování před „deštníkovou sociologii “ a potvrzuje naléhavost jeho apelu na „,návrat k teorii““. Pakliže totiž budeme vnímat prostor studia religiozity v české sociologii jako „datově nasycený“, avšak explanačně či interpretačně nenaplněný, nelze hledat cestu k nápravě (pouze) ve zkvalitnění metodologické práce, ale $\mathrm{v}$ zásadnějším a současně reflexivnějším nakládáním $\mathrm{s}$ teoretickými nástroji.

V této souvislosti si připomeňme slova Miloše Havelky o teoriích, které „nejsou jen cílem poznání, ale také jeho předpokladem a prostředkem“ (Havelka 2010: 87). Budeme-li $\mathrm{k}$ teoriím a teoretickým konceptům přistupovat jako k nástrojům, které „usnadňují empirické zkoumání sociálního světa kladením teoreticky zajímavých otázek, poskytováním konceptuálních nástrojů pro komparativní práci, pro přecházení z jedné úrovně analýzy ke druhé“ (Mouzelis 1995: 8), dává smysl podrobit bližšímu zkoumání otázky, které si česká sociologie náboženství v posledních letech kladla, a způsoby, jakými pritom nakládala se (sociologickou) teorií. 
Tato sociologická subdisciplína zaznamenala v posledních dvou dekádách poměrně dynamický rozvoj, což dokládá rostoucí počet odborných publikací. Rešerše relevantních titulů ukazuje, že dominantním tématem polistopadové české sociologie náboženství je na evropské i světové poměry nizká míra tradičníinstitucionalizované religiozity. Uplynulá léta dala vzniknout množství studií, které se tento fenomén snažily sociologicky popsat a analyzovat (např. Mišovič 2001; Lužný - Navrátilová 2001; Spousta 2002; Nešpor 2004; Václavíková Helšušová - Václavík 2006; Lužný - Nešpor a kol. 2008; Nešporová - Nešpor 2009; Hamplová - Nešpor 2009; Hamplová - Řeháková 2009; Hamplová 2000, 2001, 2008; Václavík 2014).

V této stati se zaměřuji na tři vybrané monografie, které se problematice české „bezbožnosti“ důkladně a na empirické bázi věnovaly. Všechny vyšly v poslední dekádě a všechny si vytkly za cíl podat zprávu o stavu religiozity v současné české společnosti. Jedná se o tyto publikace: David Václavík Náboženství a moderni česká společnost (Grada, 2010) ${ }^{3}$, Zdeněk R. Nešpor Př́liš slábi ve víre. Česká ne/religiozita v evropském kontextu (Kalich, 2010) a Dana Hamplová - Náboženství v české společnosti na prahu 3. tisíciletí (Karolinum, 2013) ${ }^{4}$. Mou reflexi prritom vedou dvě základní otázky: 1) Do jaké míry tyto práce překračují deskriptivni rovinu? 2) Jak ve své (př́ípadné) snaze postoupit za deskriptivní rovinu využívají (sociologické) teorie?

\section{Co je to teorie?}

Gabriel Abend (2008: 173) ve své podnětné studii konstatuje, že „'teorie’ je jedním z nejdůležitějších slov v lexikonu současné sociologie“. Současně se táže: „co přesně mají sociologové na mysli slovy 'teorie', 'teoretický' a 'teoretizovat'?" Chceme-li se bavit o úloze či funkci teorie, je dobré si nejprve vyjasnit, co tímto pojmem míníme, a zamezit tak sémantickému zmatku.

Již zmiňovaný Miloš Havelka rozlišuje dvě základní pojetí teorie. V prvním - reflexivním - pojetí teorie „formují předpoklady společenskovědního a historického poznání, analyzují jejich východiska i způsoby pojmotvorby“ (Havelka 2010: 90), ve druhém pak teorie slouží „k obsažnějšímu uchopení problémů, k nalezení nových faktů nebo k jejich odlišnému hodnocení, k ukázání nových souvislostí mezi událostmi, k jejich přesvědčivějším interpretacím atp.“ (tamtéž: 92).

\footnotetext{
3 David Václavík z hlediska oborové identity v českém akademickém prostředí nevystupuje jako sociolog, nýbrž jako religionista. Jeho monografie se však po mnoha stránkách (užitá data, konceptuální zasazení) hlásí k sociologické perspektivě. Její zařazení do předkládané analýzy proto pokládám za legitimní.

4 Případná námitka, že tyto monografie mají omezenou vypovídací hodnotu, protože klíčový vědecký výstup v současném akademickém provozu představují časopisecké studie, obstojí jen zčásti. Ve dvou ze tří př́ípadů (Nešpor, Hamplová) je totiž př́islušná monografie souhrnem poznatků, které byly dříve publikovány časopisecky.
} 
Jinou dichotomii nabízí - Petruskem diskutovaný - Nikos Mouzelis (1995), který na teorii pohlíží skrze její dva základní typy: a) jako soubor navzájem provázaných a empiricky testovatelných substantivních tvrzení, která nám sdělují o sociálním světě něco nového ( $\rightarrow$ teorie jako provizorní koncový produkt) a b) jako soubor nástrojů, které nám usnadňují či připravují základy pro budování substantivní teorie ( $\rightarrow$ teorie jako nástroj).

Jak ovšem dokládá výše zmiňovaný Abend, při snaze zachytit různé významy pojmu „teorie“ si nevystačíme s pouhou dichotomizací. Sám identifikuje celkem sedm významů, na něž v souvislosti s tímto pojmem můžeme v sociologii narazit:

1) logicky propojený systém obecných propozic, které konstatují vztah mezi dvěma či více proměnnými

2) vysvětlení (nejen kauzální) určitého společenského jevu

3) interpretace či vyložení smyslu určitého výseku empirického světa

4) studium a výklad klasiků

5) světový názor, celková perspektiva pro nahližení a výklad světa, paradigma

6) normativní, politický výklad sociálního světa (sociální teorie)

7) studium určitých speciálních problémů, kterým sociologie čelí.

$\mathrm{V}$ návaznosti na Abendovu klasifikaci a v rámci rozvíjení Swedbergova konceptu teoretizování (srv. Swedberg 2016) rozlišuje Monika Krause (2016) pět způsobů teoretizování:

1) výklad významných postav

2) aplikace existujících konceptů na nová zjištění

3) propojení nového faktu či zjištění s existenciální otázkou nebo historickým trendem

4) rozvíjení nových konceptů v dialogu se zjištěními a dř́ivějšími koncepty

5) propojování konceptů do testovatelných hypotéz o kauzálních vztazích mezi jevy.

Dotýká se přitom také důležité otázky úlohy explanace v rámci sociologického teoretizování, kterou Swedberg artikuluje jednoznačně: „explanace představuje ústřední prvek teorie“"(Swedberg 2016: 11) .

Explanace jako produkt vědeckého zkoumání si zaslouží pozornost nejen ve vztahu ke konceptualizaci, ale - možná ještě více - v rámci otázky, do jaké míry př́edstavuje definiční znak teorie jako takové. Hedström a Swedberg (1998: 1) upozorňují, že zdaleka ne každá (sociální) teorie usiluje o to nabídnout vysvětlení (explanaci). Ukazuje se, že „to, co často vystupuje pod hlavičkou sociální teorie, lze spíše vnímat jako konceptuální nebo zcitlivující (sensitizing) schémata než jako explanační teorii v pravém slova smyslu“.

\footnotetext{
${ }^{5}$ Zatímco pro Swedberga představuje konceptualizace - ve smyslu rozvíjení či zdokonalování konceptů - pouze nutný krok na cestě $\mathrm{k}$ explanaci, hájí Krause stanovisko, že „konceptualizace nemusí být vždy podřízena explanaci coby konečnému cíli“" (Krause 2016: 27).
} 
Tento fakt se ostatně promítá do výše prezentovaných typologií Abenda a Krause, ve kterých je označení „,teorie“ rezervováno i pro jiné (non-explanační) poznávací praktiky (např́klad deskripce či interpretace) ${ }^{6}$.

Pohlédněme proto na následujících řádcích na vybrané české publikace ze sociologie náboženství prizmatech užití (sociologické) teorie jako explanačního nástroje.

\section{Teorie v sociologických publikacích o české religiozitě}

V předmluvě své práce Náboženství a moderní česká společnost deklaruje David Václavík, že její ambicí „není podat vyčerpávající přehled a detailní analýzu role náboženství v moderní české společnosti a postoje Čechů vůči náboženství a jednotlivým náboženským skupinám. Vytyčený cíl je mnohem skromnější - základní orientace (kurzíva RV) v problému, který se zdá být jedním z nejkontroverznějších témat moderní české historie“ (Václavík 2010: 7). Oním „problémem“ má Václavík na mysli vztah Čechů k náboženství, jehož veřejnou reflexi podle něj provází řada neopodstatněných představ, a to zejména pokud jde o př́ičiny (údajné) české sekulárnosti či „ateističnosti“. Narušení těchto představ reprezentuje hlavní autorův záměr, jak dokládá pasáž ze závěru práce: „Cílem této práce nebyla vyčerpávající deskripce ani snaha o normativní výklad 'dějin náboženství' v jedné sekularizované středoevropské zemi, ale spíše metodicky ukotvená dekonstrukce některých značně rozšiřrených představ týkajících se vztahu Čechů k náboženství “ (tamtéž: 213).

Teoreticko-konceptuální rovina vstupuje do Václavíkova textu záhy - jeho první kapitola se věnuje vybraným teoriím a konceptům relevantním pro zkoumání vztahu náboženství a moderní společnosti. Ústřední roli přitom sehrávají koncepty (kolektivní) identity a sekularizace. Za zmínku přitom stojí, že obsah kapitoly autor uvozuje slovy o „obecnějších metodologických problémech spojených zejména s vymezením klíčových pojmů“ (Václavík 2010: 7). Podobně jako $v$ prípadě Váněho zhodnocení aktuálního stavu empirického výzkumu náboženství v Česku je i zde „teorie“ zneviditelněna ve prospěch „metodologie“. Procházíme-li přitom příslušné stránky, narážíme na důležité teoretické př́spěvky nabízející vysvětlení či interpretaci pozice náboženství v moderní době (P. Berger, T. Luckmann, B. Wilson, D. Martin, J. Casanova, G. Davie). Na konci dané kapitoly se pak Václavík přihlašuje k teorii/konceptu modernizace mad'arského sociologa Miklóse Tomky, která (byt' vyložená v sotva dvou odstavcích) podle něj po náležité modifikaci představuje důležitý explanační nástroj:

\footnotetext{
${ }^{6}$ K důkladné reflexi otázky povahy sociálněvědního poznání a vztahu mezi teorii a empirickou evidencí viz Reed (2011); pro souhrn hlavních Reedových argumentů srov. MacColman (2015).
} 
„Pro adekvátní pochopení proměny vztahu náboženství a české společnosti je tato koncepce dvourychlostní modernizace klíčová. Umožňuje lépe vysvětlit (kurzíva RV), proč se současná náboženská situace v České republice více než situaci ve většině států bývalého sovětského bloku podobá situaci v takových zemích, jakými jsou Francie, Nizozemsko či skandinávské státy, a zároveň snad jednou provždy vyvrátit hluboce zakořeněnou a stále hojně rozšířenou tezi, že za vysokou mírou sekularizace a 'ateizace' české společnosti může komunistický režim“ (Václavík 2010: 50).

Klíč ke zodpovězení otázky po zdroji postoje české populace k náboženství je podle Václavíka zapotřebí hledat $\mathrm{v}$ historickém průběhu modernizačního procesu v českých zemích: „Chceme-li lépe pochopit a adekvátně vysvětlit (kurzíva RV) důvody 'specifického' českého postoje k náboženství, musíme se obrátit hlouběji do minulosti“" (Václavík 2010: 52). Po obsáhlé analýze, která čerpá z historických a sociologických zdrojů, pak Václavík dochází k jasně artikulovanému závěru: „Jediným akceptovatelným vysvětlením (kurzíva RV) je charakter a hloubka procesu modernizace, který vedl spolu s náboženskou uniformitou české společnosti v 19. století k podkopání základů tradiční společnosti a tím i znedůvěryhodnění tradičních náboženských instituci" (tamtéž: 213). Toto vysvětlení autor klade do kontrastu s jinými „interpretacemi“ (tamtéž), na které lze v českém prostředí v této otázce narazit.

Václavíkova práce predstavuje $\mathrm{v}$ několika ohledech pozoruhodný text. V prvé řadě jde o jeho nekonzistentnost, co se týče jeho ambice i žánru. Navzdory v úvodu deklarovanému „skromnému cíli“ v podobě „základní orientace v problému“ předkládá otevřenou polemiku s nejrozšiřrenějšími vysvětleními příčin vysoké míry sekularizace české společnosti (resp. „kritickou reflexi“"), která se opírá o kombinaci historické a sociologické analýzy. Václavíkův přístup je přitom svou základní myšlenkou inspirativní - prezentuje totiž nízkou míru (tradiční) religiozity v české společnosti primárně jako důsledek specifické podoby utváření české národní identity v průběhu modernizačního procesu, jejiž podstatný prvek tvoří distance od institucionalizovaného náboženství a osvojení si př́islušného „sekularistického“ diskurzu.

Z hlediska účelu této studie se jako nejdůležitější rys Václavíkovy práce ukazuje nedostatečně reflektovaná a (proto) matoucí práce s teorií. Klíčový koncept, s nímž Václavík ve své analýze pracuje, představuje (kolektivní) identita. Teoretickým rámcem, ve kterém se v ní pohybuje, je mu teorie modernizace. A výzkumný design, který v ní využivá, reprezentuje historickokomparativní analýza. Zřetelnost těchto tř́ faktů a jejich vzájemná provázanost však není v práci explicitně předestřena. Jen sotva to lze přičíst jejímu popularizačnímu charakteru - charakteru, který je spíše deklarací než realitou. Jde spíše o obecnější trend vysledovatelný v soudobé české sociologii náboženství, 
jehož určujícím znakem je rezignace na důkladnou a systematickou práci se sociologickou teorií.

Také práce Zdeňka R. Nešpora Př́lišs slábi ve víre se odráží od obecně rozšířené teze o české společnosti jako jedné z nejméně religiózních na světě. A i ona ve svém úvodu deklaruje relativně skromný (a poměrně vágní) záměr: „Cílem této knihy (...) není nic jiného, než hlouběji prozkoumat (kurzíva RV) toto specifikum současné (a nejen současné) české společnosti a vřadit jej do širšího historického, společenského i mezinárodního kontextu“" (Nešpor 2010: 7), přičemž si neklade „nárok na úplnost, jako spíš na porozumění (kurzíva RV) ústředním tématům, otázkám a 'problémům' vztahu moderní české společnosti k (různým podobám) náboženství" (tamtéž: 13). Pokud jde o užitou metodu, pak kniha „vychází z historických a sociologických dat a př́ístupů a snaží se o jejich interpretaci (kurzíva RV) v širším mezinárodním (evropském a občas i světovém) kontextu“"(tamtéž: 7).

Podobně jako Václavíkova práce začíná i ta Nešporova „teoretickou“ kapitolou, která má i zde spíše přehledový charakter, než že by budovala teoretickou základnu, jež bude odrazovým můstkem pro originální sociologické vysvětlení či interpretaci sledovaného jevu. Stěžejní místo i v tomto případě zaujímá teorie modernizace a $\mathrm{k}$ ní přidružená teorie sekularizace, na něž navazují novější (často polemické) př́ispěvky nejrůznějšího druhu (od teorie racionální volby po historizující výklady). A konečně i v Nešporově práci následuje po teoretickém expozé obsáhlá část kombinující historický a sociologický empirický materiál, který je prezentován spíše mozaikovitě než s ohledem na jasný badatelský záměr (jakým byla u Václavíka polemika s alternativními výklady české sekularity).

Ve výsledku dochází Nešpor k podobnému závěru jako Václavík. I on zpochybňuje rozšiřrenou představu o „ateističnosti“ české populace: „Současná česká společnost tedy stále není ani tolik ateistická, i když si to o sobě 'hrdě' myslí, jako spíše proticírkevně zaměřená, přičemž vlastní náboženské potřeby a představy transformovala do deklarativně odlišných typů symbolických světů. Češi odmítají křest'anského Boha, v 'něco' však obvykle věří a současně si to 'něco' připodobňují strukturám zlomků křest'anské paměti zasutým ve společenském vědomí “ (Nešpor 2010: 188).

Př́nos Nešporova textu se projevuje tam, kde se věnuje důkladnému popisu fungování institucionalizovaného náboženství a podob individuální religiozity, a to zvláště tehdy, zmiňuje-li fakta, která nejsou sociologům, resp. ne-historikům obecně známá. V okamžicích, kdy se však odhodlá tuto rovinu překročit směrem k sociologické interpretaci či sociologickému vysvětleni (obojí př́liš nerozlišuje), vyznívá jeho úsilí rozpačitě. Sociologický konceptuálně-teoretický aparát mu neslouží k hlubšímu porozumění zkoumané problematice, ale spíše jako prostředek pro okomentování popisovaných faktů - pakliže jeho služeb 
vůbec využívá. V tomto smyslu Nešporův rozbor náboženské situace v české společnosti provází podobný nedostatek, jenž charakterizuje i Václavíkovu práci (ačkoliv ta se přece jen pokoušela dané téma interpretačně uchopit skrze sociologický koncept identity). I zde zůstává požadavek teoreticky podloženého a teorií inspirovaného sociologického zkoumání, které umožňuje klást sociologicky podnětné otázky a nacházet na ně přesvědčivé a netriviální odpovědi, nenaplněn.

Kniha Dany Hamplové Náboženství v české společnosti na prahu 3. tisíciletí představuje poslední ze sledovaných sociologických analýz současné české religiozity. Za cíl si klade „nastínit nejvýznamnější charakteristiky českého postoje $\mathrm{k}$ náboženství i vývoj, jímž religiózní představy a chování v české společnosti v posledních desetiletích prošly“ (Hamplová 2013: 7) či v jiné formulaci „popsat celkové obrysy české náboženské scény v polistopadové české společnosti tak, jak ji zachycují kvantitativní výzkumy“ (tamtéž: 139). Podobně jako Václavík a Nešpor také Hamplová poukazuje na skutečnost, že se Česká republika aktuálně jeví ,alespoň z hlediska církevní religiozity - jako jeden z nejsekulárnějších států světa“" (tamtéž: 26).

Přestože se její práce $\mathrm{z}$ analyzovaných textů nejzřetelněji hlásí $\mathrm{k}$ primárně deskriptivní ambici, přibližuje i ona $\mathrm{v}$ první kapitole vybrané teoretické koncepty, s jejichž pomocí přistupuje sociologie k náboženství (sekularizace, desekularizace, deprivatizace atd.). Autorka si jejich přehledem připravuje půdu pro konceptuální uchopení českého duchovního/světonázorového milieu, které se - což je jedním z hlavních argumentů její práce - zdaleka nevyčerpává tradičními církevními formami religiozity.

Jádro práce tvoři metodologicko-konceptuální reflexe otázky „měření“ religiozity, prezentace zjišsěných výsledků vybraných kvantitativních šetření sledujících indikátory tradiční i alternativní religiozity a zkoumání síly vztahů mezi vybranými sociodemografickými charakteristikami a religiozitou. Třetí z uvedených tematických oblastí otevírá prostor sociologickým teoriím. Při zkoumání vazby mezi religiozitou a pohlavím Hamplová explicitně rozebírá čtyři hlavní (ne výhradně sociologické) teorie usilující o vysvětlení obecně pozorované vyšší religiozity žen v porovnání s muži. Její vlastní analýza pak tuto distribuci potvrzuje a jako explanační nástroj favorizuje teorii spatřující klíčový faktor v rozdílné socializaci dívek a chlapců. V př́padě zbývajících analyzovaných sociodemografických charakteristik coby nezávisle proměnných v rámci vztahu s religiozitou už zapojení teorie oslabuje (fakticky se redukuje do poněkud neinvenčního testování Weberovy teze o „protestantské etice").

Závěr práce Dany Hamplové - podobně jako tomu bylo v případě Václavíka a Nešpora - problematizuje představu Čechů jako „nejateističtějš́ího národa světa“. Taková představa může mít dle autorky jisté opodstatnění v prŕípadě, že 
„ateismem“ míníme rezervovaný až odmítavý postoj k tradičním, tj. církevním formám religiozity, ale zdaleka neplatí, má-li se jí na mysli uzavřenost české populace duchovním impulsům jako takovým:

„Ukázali jsme, že české postoje k náboženství jsou v určitém smyslu specifické a výjimečné. Ne tím, že by Češi byli racionální jedinci odmítající náboženství a nadpřirozeno jako celek, ale tím, že se u nás kloubí odmítání tradičního náboženství s vírou v magii a okultismus či - zjednodušeně řečeno s vysokou mírou pověrčivosti“ (Hamplová 2013: 139).

Konstatovaná „specifičnost“ a „výjimečnost“ české společnosti přitom podle Hamplové „napovídá, že standardní sociologické teorie, zdůrazňující obecné vývojové trendy $\mathrm{v}$ moderních společnostech, nemůžou české postoje $\mathrm{k}$ náboženství plně vysvětlit“ (tamtéž). Tato pozoruhodná formulace však není nijak více rozvedena, takže lze pouze spekulovat, co přesně jí chtěla autorka vyjádřit. Jisté vodítko mohou poskytnout její slova o tom, že „míra odmítání církví a tradičního náboženství se zdá být $\mathrm{v}$ naší zemi silnější než v ostatních modernizovaných společnostech“ (Hamplová 2013: 139), která naznačují, že „standardni“" teorie sekularizace prripisující hlavní podíl na poklesu společenského významu tradičního/institucionalizovaného náboženství modernizačnímu procesu mohou vysvětlit pouze celkový obecný trend, avšak ztroskotávají coby nástroj vysvětlení „,specificky české“ intenzity individuální sekularizace v české společnosti.

Tam, kde Václavík s pomocí koncepce Miklóse Tomky reflektoval různorodost trajektorií modernizačního procesu, zvažuje Hamplová faktor „komunistického dědictvi“" (tedy faktor, který Václavík jakožto určující rezolutně odmítá): „Jedním $\mathrm{z}$ tradičních vysvětlení nízké nedůvěry v církve v České republice je odkaz na působení komunistického režimu a anticírkevní propagandy“ (Hamplová 2013: 139). Uvědomuje si však nedostatečnost tohoto vysvětlení, když konstatuje, že zůstává „otázkou, proč byla v české společnosti anticírkevní komunistická propaganda o tolik úspěšnější než v ostatních zemích bývalého sovětského bloku.“ Na tuto - bezesporu oprávněnou a důležitou otázku však nenabízí žádnou odpověd’. Zastavuje se tak v bodě, který pro Václavíka s Nešporem naopak představuje jádro jejich snah o vysvětlení zkoumaného jevu a legitimizaci jejich analytického ponoru do vzdálenějších období (moderní) české historie.

Pojítkem práce Hamplové s prŕspěvky Václavíka a Nešpora je naopak skutečnost, že teoreticko-konceptuální přehled, se kterým čtenáře $\mathrm{v}$ jejím úvodu seznamuje, není v následující analýze nijak systematicky využit. Netvoř́i základnu ke konstrukci jasného teoretického rámce, jehož prostřednictvím by se autorka snažila čtenářum sdělit více, než co říkají výstupy z užitých statisticko-analytických procedur - tj. nabídnout sociologické vysvětlení nebo 
sociologickou interpretaci, které překračují rovinu popisu empirických dat a elementárních statistických vztahů mezi nimi ${ }^{7}$.

\section{Přešlapování na místě}

Pohlédneme-li na dané práce perspektivou typologií Gabriela Abenda a Moniky Krause, můžeme konstatovat, že pakliže je v nich práce s teorií př́tomna, má sloužit $\mathrm{k}$ vysvětleni určitého společenského jevu (příčiny či zdroje nízké míry tradiční religiozity) nebo interpretaci určitého výseku empirického světa (postoje české populace $\mathrm{k}$ tradičnímu náboženství či povahy české religiozity). Faktické využití sociologické teorie při naplňování daných cílů je však velmi skromné, nesystematické a eklektické. Z větší části nabývá formy „aplikace“ existujících konceptů na empirická zjištění odvozená z aktuálních i historických dat. S částečnou výjimkou práce Dany Hamplové absentuje práce s teorií jako s logicky propojeným souborem obecných propozic o vztahu mezi proměnnými a snaha propojovat vybrané koncepty do testovatelných hypotéz o kauzálních vztazích mezi pozorovanými jevy.

Současně je třeba poznamenat, že společným rysem všech tř́i analyzovaných prací je svébytný polemicko-apologetický rozměr namířený proti obecně rozšířené představě o české populaci jako jedné z nejsekulárnějších, nejbezbožnějších či nejateističtějších. V prípadě Václavíka jde o snahu ukázat, že četnými empirickými výzkumy indikována česká „bezbožnost“ je spíše projevem historicky utvořené distance $\mathrm{k}$ institucionalizovanému/církevnímu náboženství (a s ním spjatému chápání ústředních pojmů jako „,náboženstvi““ či „věrícíi“). Podobně i Nešpor (2010: 187) naznačuje, že př́slušná diagnóza souvisí se „zúženým pojetím náboženstvi““ a že dnešní česká společnost je „spíše proticírkevně zaměřená“ než „ateistická“. Hamplová (2013: 136) potom přímo prohlašuje, že v souvislosti s Českem ,nic nemůže být vzdálenější pravdě“ než titul „nejateističtějš́ího národa světa“, načež konstatuje nízkou míru víry v Boha v české populaci za současného rozšiřrení různých forem alternativní religiozity (magie, okultismus).

Přes nepochybný přínos uvedených prací česká sociologie náboženství zkoumající povahu zdejšího náboženského života stále čeká na stěžejní studii, která by vykročila za hranice souhrnných empirických popisů a historicky orientovaných exkurzů a předložila teoreticky kvalitně připravený počin srovnatelný s takto zaměřenými studiemi z jiných zemí (např. Froese - Pfaff 2005; Stolz et al. 2016; Kreting et al. 2018). Z hlediska zájmu o hlubší proniknutí do labyrintu české religiozity a vykreslení obsáhlejšího obrazu „českého př́běhu“ zdejší badatelská obec už jistý čas přešlapuje na místě a teoretické impulzy,

\footnotetext{
7 Podobně ve své recenzi tematicky příbuzné práce Hamplové a Řehákové (2009) konstatuje Dušan Lužný, že jejím největším nedostatkem je "teoretická a konceptuální neukotvenost při práci s empirickými daty“ (Lužný 2010: 836).
} 
které by jí z této stagnace mohly pomoct vykročit, zužitkovává jen pomálu (Pabian 2013; Váně - Štípková 2013).

Jak bylo ilustrováno výše, významná část zdejší sociologické produkce zaobírající se analýzou české religiozity se zásadní měrou obrací k historickým výkladům: vysvětlení pro „specifičnost“ české religiozity je podle nich třeba hledat ve „specifičnosti“ (moderní) české historie. Není pochyb o tom, že „ahistorické“ makrosociologické teorie nám jen sotva poskytnou uspokojivou detailni odpověd' na otázku po zdroji konkrétní (,specifické“) podoby náboženského života v Česku. To ze své povahy ani učinit nemohou. To ovšem neznamená, že bychom sociologické studium náboženství mělo rezignovat na teorii jako takovou a spoléhat se na ,idiografické“ výklady jedinečnosti národních historií. Historizující sociologické studie proklamující „výjimečnost“ české religiozity navíc charakterizuje určitý problematický rys, který vystihuje Petr Pabian, když uvádí, že „většina literatury o náboženství v moderním Česku tuto výjimečnost a sekularitu spíše předpokládá, než že by ji analyzovala“" (Pabian 2013: 85). Jeho výtka míŕí na absenci komparativní perspektivy a nedostatečnou přesvědčivost předkládaných interpretací.

Přes skeptický tón př́tomný ve výše uvedených řádcích je třeba konstatovat, že v posledních letech začala česká sociologie náboženství svůj teoretický „deficit" více reflektovat a hledat cesty $\mathrm{k}$ jeho (alespoň částečné) nápravě. Př́kladem může být zapojení konceptu paměti do studia náboženského vývoje české religiozity (Havlíček 2016; Vido 2016) nebo volání pro (větším) využití perspektivy teorie racionální volby (Lužný 2015) či impulzů z kognitivních věd (Lužný 2012) ${ }^{8}$. Ani tyto pozitivní signály však nemohou zakrýt základní fakt, jímž je dosavadní explanační deficit.

Na následujících řádcích představuji možný směr, kterým se lze na vymezeném poli ubírat. Vycházím přitom z přesvědčení, že českou sociologii náboženství charakterizuje absence propracované a přesvědčivé studie, která by podstatným způsobem přispěla k sociologickému vysvětleni aktuální podoby náboženského života současné české populace. Naznačený směr přitom nemá nijak upírat právo na existenci jiným výzkumným programům, poznávacím cílům či sociologickým žánrům.

\section{Analytická inspirace: koncept sociálních mechanismů}

Jeden z nejpodnětnějších sociologických příspěvků posledních let, který se důkladně zaobírá problematikou sociologického vysvětlování religiozity, předsta-

\footnotetext{
8 Jako v principu inspirativní lze v tomto ohledu hodnotit také studii slovenské socioložky Adély Kvasničkové (2005), která staví na teorii kolektivní paměti Maurice Halbwachse a na ni navazujících koncepcích Danièle Hervieu-Léger a Grace Davie, nebo práci jejího slovenského kolegy Miroslava Tížika (2011), která při interpretaci náboženského vývoje v moderní slovenské společnosti čerpá z teoretických př́stupů Emile Durkheima, Pierra Bourdieu nebo Petera L. Bergera a Thomase Luckmanna.
} 
vuje studie švýcarského sociologa Jörga Stolze (2009a), v níž se její autor hlásí $\mathrm{k}$ analytické sociologii ${ }^{9}$. Tento př́stup navazuje na některé dř́vějšś teoretické $\mathrm{i}$ empirické příspěvky ze sociologie i jiných vědeckých disciplín (zejména ekonomie) a ve své aktuální podobě, která se konstituovala v průběhu 90. let, představuje originální badatelský směr (Manzo 2010). Přes některé významné spojující články (viz dále) jej nelze ztotožňovat s př́stupem teorie racionální volby (rational choice theory) (Hedström - Ylikoski 2010). V prostředí české/československé sociologie dosud nenachází výraznější ohlas ${ }^{10}$.

Poznávací ambicí analytické sociologie je sociologická explanace. Stojí na principu metodologického individualismu, podle něhož se sociální svět skládá z různých úrovní, jež jsou navzájem kauzálně propojené. Sociologické vysvětlení se pak snaží jevy z mezo- a makroúrovně vyložit jako výsledek jednání jedinců na mikroúrovni. Každé „,srozumitelné sociálněvědní vysvětlení by mělo vždy zahrnovat explicitní odkazy k prí̌činám a následkům jejich jednání“ (Hedström - Swedberg 1998: 11-12). Jednající jedinci přitom fungují ve vzájemných interakcích, které se liší svojí povahou a strukturou. „Lze potom tvrdit, že odlišné typy strukturálních konfigurací aktérů konstituují odlišné sociální mechanismy" (Hedström 2005: 26).

Jak upozorňuje Hedström (2005), ve vědecké literatuře existují nejméně tři typy explanací, které se liší odpověd’mi, jež nabízejí na „proč-otázky“ (whyquestions). První je vysvětlení obecným zákonem, jehož podstatu tvoří vyložení určitého pozorovaného jevu jako případu obecně platné zákonitosti formulované př́islušnou teorií. Může mít přitom deduktivně-nomologickou nebo induktivně-probabilistickou variantu. Druhé vysvětlení je statistického typu. Opírá se o induktivní logiku a jde mu o nalezení faktorů, které dokáží s nejvyšší pravděpodobností predikovat pozorovaný jev. Teorie $\mathrm{v}$ tomto př́ípadě nestojí na začátku výzkumného úsilí, nýbrž na jeho konci. Třetí typ vysvětlení se soustředí na mechanismy, které generují určité jevy. Neodvolává se na obecné zákony ani neodhaluje statisticky relevantní faktory, ale specifikuje konkrétní sociální mechanismy, které dávají pozorovaným jevům vzniknout.

Př́nos perspektivy sociálnich mechanismů spočívá v rozkrytí toho, co bývá při sociologickém vysvětlování prvního typu (implicitně) vnímáno jako „black box“, totiž vazba konkrétního chování či jednání individuálních aktérů na vysvětlované sociální jevy na vyšších úrovních sociální reality ${ }^{11}$. Platí přitom, že

\footnotetext{
${ }^{9}$ V jiném svém textu (Stolz 2009b) se výslovně hlásí k ambici vnést teoretické podněty z analytické sociologie, ke které jej přivedla práce Raymonda Boudona, do oblasti svého zájmu - totiž sociologie náboženství.

${ }^{10}$ Výjimkou jsou práce slovenského sociologa Juraje Schenka, jenž se oblastí, kterou analytická sociologie pokrývá (např. v souvislosti s tzv. multiagentním modelováním), dlouhodobě a systematicky zabývá (viz Schenk 2014, 2017). Z českých autorů viz kratší text T. Diviáka (2018).

11 Dokladem existence takového „black boxu“ mohou být (některé) sekularizační teorie. Jak ve své analýze sekularizace východního Německa poznamenávají Froese, Pfaff (2005: 401-402): „Modernizační teorie předpokládá, že důležitost náboženství klesá s tím, jak vědecký světonázor nahrazuje světonázor náboženský a technologie pronikají každodenní praxí
} 
sociální jevy bývají výsledkem souběžného fungování různých sociálních mechanismů (a tedy kauzálních procesů), jejichž konkrétní vliv se může lišit př́ipad od př́ípadu ${ }^{12}$. Uvedený postup přitom nelze zaměňovat s deskriptivními postupy, které chtějí „zaznamenat jedinečný řetězec událostí, který vedl od jedné situace či události k jiné". Př́ístup založený na sociálních mechanismech předpokládá, že „existují obecné typy mechanismů, jež můžeme nalézt v pestré škále rozličných sociálních prostředí, které fungují podle stejných logických principư" (Hedström - Swedberg 1998: 2).

Sociální mechanismy lze obecně klasifikovat na situační mechanismy (situational mechanisms), mechanismy formující jednání (action-formation mechanisms) a transformační mechanismy (transformational mechanisms) (obrázek č. 1). Kritérium pro jejich rozlišení tvoří výsek v modelu víceúrovňové sociální reality, o jehož vysvětlení usiluje ${ }^{13}$. Situační mechanismy reflektují působení makrosociálních podmínek na individuálního aktéra. Mechanismy formující jednání jsou lokalizovány na mikroúrovni a zachycují vztah mezi individuálními přesvědčeními, preferencemi a př́ležitostmi na straně jedné a individuálním jednáním na straně druhé. Transformační mechanismy explanačně pokrývají vazbu mezi mikroúrovní a makroúrovní.

Také Jörg Stolz zdůrazňuje, že podat sociologické vysvětlení znamená „ukázat, jak výchozí situace (makro) vede jedince k reakci na tuto situaci (mikro) a jak prostř̌ednictvím nakupení těchto individuálních reakcí dochází k vytvoření nového sociálního výsledku (makro)“ (Stolz 2009a: 347). „Sociální mechanismus“, který se ocitá ve hře, zahrnuje: a) př́ležitosti (opportunities), normy (norms) a kulturní zdroje (cultural resources) prítomné v daných situacích; b) „racionální“14 jednání založené na přesvědčeních (beliefs) a preferencích (preferences) různých jedinců reagujících na tyto situace; c) skutečnost, že jejich reakce mohou vést k rozličným zamýšleným i nezamýšleným důsledkům. Aplikujeme-li toto schéma při sociologickém vysvětlování religiozity ${ }^{15}$, půjde nám o to „ukázat, jaké vlastnosti výchozích situací (pokud jde o př́ležitosti, normy a kulturu) povedou jedince $\mathrm{k}$ racionálnímu přizpůsobení se výběrem více (či méně) náboženského jednání, čímž po agregaci individuálních

lidí. Zatímco aktuální mechanismus sekularizace je skryt (kurzíva RV), má se za to, že nové technologie, demokratické politické struktury, egalitarismus a multikulturalismus vyvolávají u věřících 'krizi důvěrohodnosti'."

${ }^{12}$ Ve své starší studii, v níž Stolz (2009a) předložil svůj obecný explanační model, současně - s jeho využitím - zkoumal situaci tradiční (křest’anské) a alternativní religiozity v moderní švýcarské společnosti. Pátral přitom po těch mechanismech, které danou situaci nejlépe vysvětlují. A došel k závěru, že v př́ipadě křest'anské religiozity analýza jako mechanismus, který ji vysvětluje nejlépe, odhalila socializaci; u alternativní religiozity pak šlo o mechanismus deprivace (plus efekt věku a genderu).

Tento model vychází z práce Jamese Colemana (1986) a pracuje pouze se dvěma úrovněmi sociální reality (mikro a makro; meziúroveň v něm zahrnuta není).

14 Jde přitom o „omezenou racionalitu“ (bounded rationality) v pojetí Herberta A. Simona (srov. též Boudon 2011 a jeho koncept „,b̌̌žné racionality“ (ordinary rationality)).

${ }^{15}$ Stolz rozlišuje mezi religiozitou (religiosity) jako individuálním jevem a náboženstvím (religion) jako kulturním a systémovým jevem. 
jednání dojde k vytvoření rozdílů v religiozitě, o jejichž vysvětlení usilujeme“ (Stolz 2009a: 348).

\section{Obrázek č. 1: Typologie mechanismů}

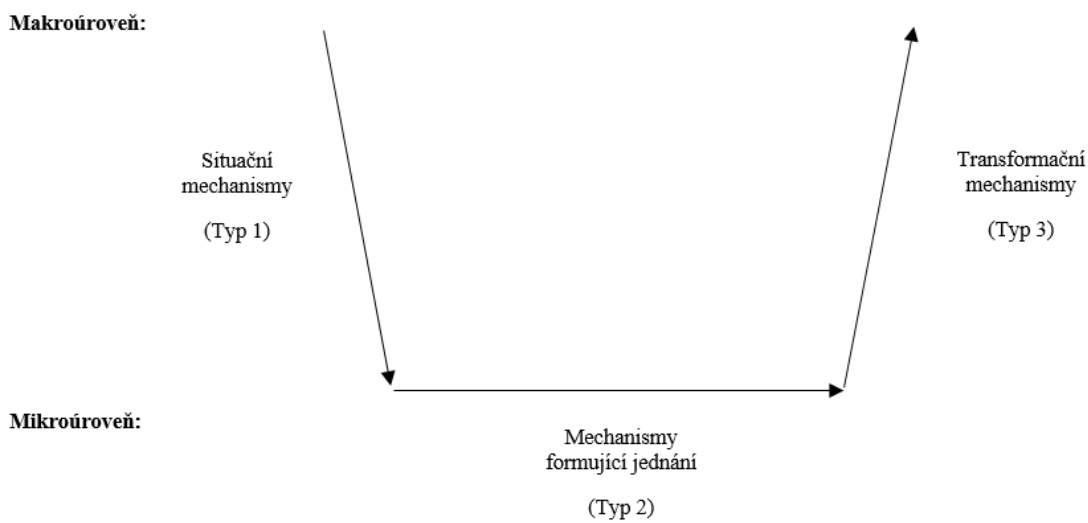

Zdroj: Hedström - Swedberg (1998: 22).

Stolz uvádí, že pro vysvětlení míry a vývoje religiozity ve společnosti existuje řada teorií. Zaměřuje se na pětici z nich, které pokládá za nejvýznamnější: deprivační teorii, teorii náboženského trhu, modernizační teorii, teorii etnicity a socializační teorii. Tyto teorie nepokládá za navzájem se vylučující, nýbrž za komplementární a vzájemně různě propojené. Dle jeho názoru je není vhodné posuzovat $\mathrm{s}$ ohledem na to, která z nich je „správná“, tj. která z nich nabízí vševysvětlující mechanismus: „Povaha sociální a historické reality je taková, že v ní funguje mnoho různých ekonomických, sociálních, technických a historických mechanismů v různých časech a na různých místech" (Stolz 2009a: 346). Záleží na konkrétním historicko-geografickém kontextu, zda a jak silně ten či onen mechanismus ve společnosti působí ${ }^{16}$.

Stolzovou snahou je zkonstruovat teoretický model, který by explanační př́nos jednotlivých teorií integroval. Za tímto účelem identifikuje nejdůležitější (implicitní či explicitní) mechanismy, s nimiž dané teorie pracují, aby je reformuloval jako „vzájemně se doplňující, na racionálním jednání založené makromikro-makro mechanismy“ a včlenil do jednoho společného teoretického rám-

16 Stolz se tímto vymezuje vůči stoupencům teorie racionální volby v sociologii náboženství (např. Iannaccone 1992 nebo Stark - Finke 2000), kteří mají tendenci redukovat explanaci religiozity na jediný mechanismus: náboženskou nabídku na náboženském trhu (za současného předpokladu konstantní náboženské poptávky). Zároveň nepočítají s variantou, že součásti „náboženského trhu“ mohou být sekulární „produkty“ coby substituty „produktư“ náboženských. Obě uvedené skutečnosti pokládá Stolz $(2009 b)$ za „epistemologické překážky“ na cestě k uspokojivé teorii racionální volby v rámci sociologie náboženství. 
ce (srov. Stolz 2009a, 2009b). Základ pro tuto strategii tvoří obecný model jednání rozpracovaný německým sociologem Hartmutem Esserem, jehož upravenou verzi zachycuje obrázek č. 2 :

\section{Obrázek č. 2: Explanační model jednání}

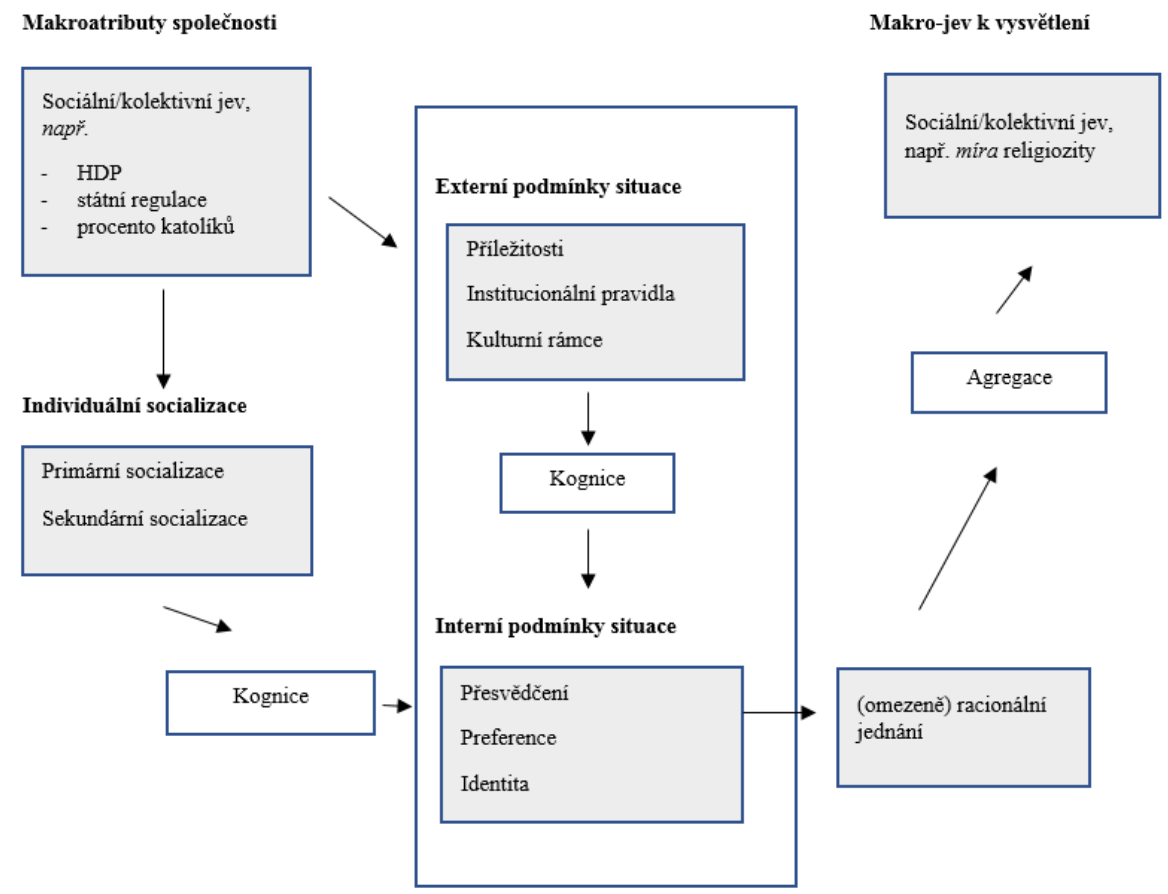

Zdroj: Stolz (2009a: 348).

Přednost předloženého modelu, který předpokládá (omezeně) racionálního jedince reagujícího jak na př́ležitosti, tak na institucionální a kulturní kontext (a obojím je tak utvářen), tkví podle Stolze ve schopnosti zřetelně propojit různé úrovně sociální reality. Jeho výchozí bod je přitom situován na mikroúroveň $\mathrm{v}$ podobě jedince racionálně se rozhodujícího mezi náboženskými a sekulárními alternativami ${ }^{17}$.

Zasadí-li se do tohoto modelu př́slušné sociologické teorie religiozity, vyvstane následující obrázek vlivu makrostrukturálních vlastností společnosti a externich podminek situace na religiozitu: Deprivační teorie orientuje svoji pozornost na externí podmínky situace, a to zejména na oblast př́ležitostí -

17 Stolz přitom počítá s efektem rutinizace rozhodnutí, který výrazně umenšuje množství voleb, které jedinci reálně činí. 
míra sociální či ekonomické deprivace na makroúrovni (např̀. materiální blahobyt, funkčnost sociálního státu nebo kvalita zdravotní péče) ovlivňuje míru deprivace na individuální úrovni. Teorie náboženského trhu se soustředí na mechanismus v podobě regulace, který se vztahuje primárně na normy. Regulována na „náboženském trhu“ může být - prostřednictvím státu a jím prosazovaných norem a pravidel - jak nabídka (supply), tak i poptávka (demand). Modernizační teorie souvisí s mechanismem produkce sekulární (resp. náboženské) kultury, se kterou jedinci přicházejí do kontaktu - at' už prostřednictvím veřejných institucí a médií, tak skrze každodenní interakce mezi jedinci. Tento mechanismus se nejvýrazněji dotýká kulturních rámců; ovlivňuje však také prŕležitosti, které jsou pro jedince dostupné. Teorie etnicity obnáší mechanismus etnického a kulturního stvrzení identity, který se stává důležitým v situacích rychlé společenské a kulturní změny nebo rozsáhlých migračních procesů, jež dopadají na populaci určité společnosti (nebo její část). V důsledku toho jsou i $\mathrm{v}$ tomto př́padě ovlivněny především kulturní rámce a př́ležitosti některých aktérů, což vede k potřebě posílení kulturní či etnické identity (včetně náboženské). A konečně socializační teorie zahrnuje mechanismus socializace jako jeden z klíčových způsobů ovlivňování přesvědčení a preferencí dětí. V této souvislosti je podstatné sledovat, jaké podmínky (normy a př́ležitosti) posilují či naopak oslabují potřebu rodičů podrobovat své potomky náboženské socializaci.

Součástí celkového schématu jsou vedle makrostrukturálních vlastností společnosti a externích podmínek situace také interní podmínky situace, které sestávají z přesvědčení, preferencí a identity jedinců, významně formovaných individuální socializací (zejména ze strany rodičů a vrstevnických skupin). Zatímco vliv socializace nepodléhá možnosti racionální volby, jiná část interních podmínek ano. Pokud jde o individuální přesvědčení, mủže jedinec volit přislušná náboženská či sekulární řešení svých životních problémů, přičemž je výraznou měrou závislý na svém ,informačním prostředí“ (information environment). Podobně je tomu i v prŕípadě preferencí, u nichž lze také volit mezi náboženskými a sekulárními alternativami. Stolz v tomto kontextu hovoří o funkcích sociální produkce (social production functions) ${ }^{18}$, které odkazují ke způsobům, jimiž se $\mathrm{v}$ jednotlivých společnostech propojují žádané cíle a akceptovatelné prostředky $\mathrm{k}$ nim vedoucí.

Shrneme-li základní sdělení Stolzem navrženého teoretického modelu, dojdeme k následující formulaci: „S ohledem na své vědění a své preference a s oporou ve svém zhodnocení př́ležitostí, institucí a kulturních rámců jedinci volí jednání, které se - z jejich subjektivního hlediska - jeví poskytovat největší užitek“" (Stolz 2009a: 357-358). Model přitom na abstraktní rovině

\footnotetext{
18 Jedná se o institucionalizované řetězce vztahů mezi cíli a prostředky (Stolz 2009b). Stolz tento koncept přebírá od německého sociologa Siegwarta Lindenberga.
} 
předpokládá, že jedinci budou ve svém jednání upřednostňovat náboženskou volbu v situacích a) zvýšsené deprivace (za současné nízké dostupnosti sekulární varianty řešení), b) vyššího tlaku institucionalizovaných norem a sankcí k projevování religiozity, c) nižší produkce sekulární kultury, d) vyššího ohrožení etnické či kulturní identity v důsledku sociální či kulturní změny a e) podstoupení náboženské socializace. Tendence k preferování náboženské socializace vlastních dětí bude silnější za podmínky fungování náboženství jako důležitého „kulturního kapitálu“.

Probíraný explanační model Stolz v pozdějších letech rozvinul do podoby nové teorie nábožensko-sekulární konkurence (Stolz et al. 2016; Stolz - Tanner 2017). Ta má být alternativou $\mathrm{k}$ trojici nejvlivnějších teorií, kterými současná sociologie náboženství disponuje: sekularizační teorie (secularization theory), individualizační teorie (individualization theory) a tržní teorie (market theo$r y)^{19}$. Tyto teorie podle Stolze prrinesly řadu cenných sociologických poznatků, vykazují však také některé deficity. Sekularizační teorie, opírající se o koncept modernizace, (často) postrádá aktérskou (mikro)perspektivu, jasně artikulovanou představu působících kauzálních mechanismů a cit pro historicko-geografický kontext. Individualizační teorie rovněž nedává velký prostor aktérské perspektivě, současně má nedostatečnou empirickou oporu a využívá př́liš širokou (funkcionální) definici náboženství. Tržní teorie aktérskou perspektivu neopomíjí, stejně tak předkládá jasnou představu působícího kauzálního mechanismu. Ve druhém bodě ovšem tkví i její slabina: nadměrně totiž působení př́slušného mechanismu (náboženské nabídky) zobecňuje napříč časem a prostorem.

Teorie nábožensko-sekulární konkurence (theory of religious-secular competition) pohlíži na náboženskou změnu jako na „výsledek nábožensko-sekulární a vnitronáboženské konkurence na různých úrovních" (Stolz et al. 2016: 19). Konkrétní výsledek, vzešlý z konkurenčního prostředí, v němž figuruje množství individuálních a kolektivních aktérů, závisí na různých externích faktorech (institucionální režim konkurence, vědecko-technologické a společenské inovace, významné historické události). Zdroje, o jejichž získání probíhá konkurenční souboj, Stolz dělí do tř́ kategorií: a) moc na úrovni společnosti jako celku, b) moc, vliv a autorita vykládat na úrovni skupin, organizací a milieu, c) individuální poptávka po statcích (čas, energie, finanční podpora atd.) ${ }^{20}$. Zapojení aktéři pritom ve svém úsilí disponují rozličnými zdroji (ekonomický

\footnotetext{
19 Tento soubor teorií se jen částečně překrývá s pěticí sociologických teorií, na které odkazoval při své dřívější konstrukci explanačního modelu religiozity (viz Stolz 2009a). Vedle intelektuálního posunu může být důvodem skutečnost, že v tomto novějším případě jde o soubor sociologických teorií, které usilují o vysvětlení změn, jimiž prochází náboženství v moderních společnostech, nikoliv (jen) o obecné vysvětlení distribuce religiozity.

${ }^{20}$ V novější verzi Stolz rozlišuje dva typy nábožensko-sekulární konkurence: 1) vztahující se na individuální jednání a volby, 2) vztahující se na societální pravidla a regulace (Stolz - Tanner 2017).
} 
kapitál, společenská reputace, technické know-how apod.) a užívají rozmanitých strategií (mobilizace, vymezování se, kvantitativní růst apod.).

Klíčovým faktorem společenské změny s ohledem na pozici náboženství je měnící se „výhodnost“" náboženství a náboženských struktur v průběhu času. Postavení a vliv náboženství ve společnosti se odvíjí od jeho schopnosti nabízet jedincům řešení problémů, které jsou pro ně aktuální (a které mohou mít rozmanitou povahu), a být tak pro ně - v případné konkurenci se sekulární „nabídkou“ - preferovanou „racionálni““ volbou. Pakliže s sebou např́klad společenský vývoj přináší sekulární technologické či sociální inovace, které naplňují individuální „poptávku“ lépe než jejich stávající náboženské alternativy, povede to v dlouhodobější perspektivě a z hlediska agregovaných účinků ke společenskému ústupu náboženství a náboženských struktur.

Soustředíme-li na nábožensko-sekulární konkurenci na individuální úrovni, vyvstane před námi následující analytické schéma (viz obrázek č. 3):

\section{Obrázek č. 3: Struktura teorie nábožensko-sekulární konkurence na indi-} viduální úrovni

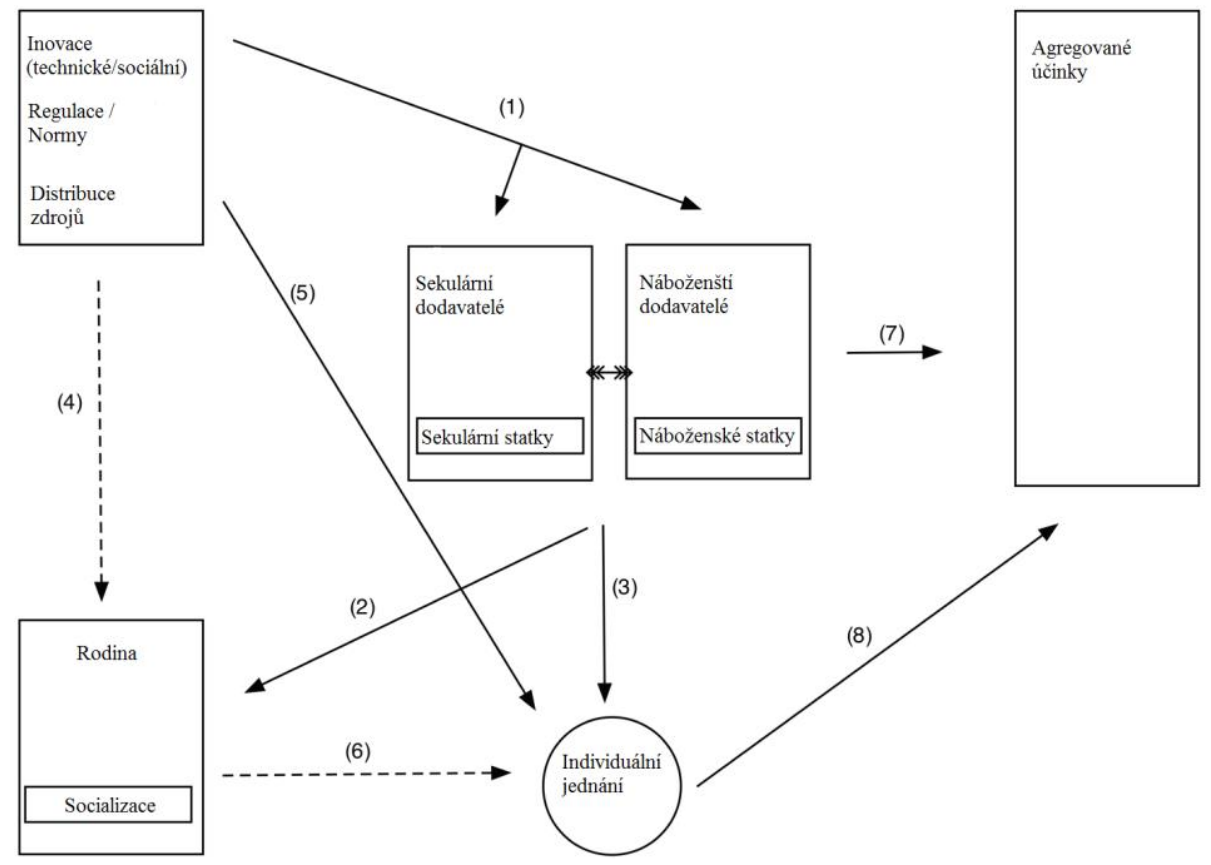

Zdroj: Stolz - Tanner (2017: 302).

Chceme-li sociologicky vysvětlit stav religiozity ve společnosti na makroúrovni, musíme vycházet $\mathrm{z}$ určitých makrosociálních podmínek (inovace, 
regulace, distribuce zdrojů), které působí na rozmanité (kolektivní) aktéry na náboženském trhu (včetně aktérů sekulárních). Tito aktéři v rámci konkurenčních vztahů usilují o získání pozornosti, času, energie či financí ze strany jedinců a rodin. Makrosociální podmínky působí na jednání jedinců a rodin také př́mo. Důležitý prvek modelu představuje socializace jedinců (v prostředí rodiny), $\mathrm{v}$ jejímž průběhu se utváří individuální preference a přesvědčení. Agregovaná jednání jedinců a „dodavatelư“ (suppliers) náboženských/sekulárních „statkư“ (goods) ${ }^{21}$ pak ústí v agregované účinky na makrosociální úrovni.

Předložená teorie podle Stolze naplňuje základní požadavky formulované proponenty analytické sociologie. Rozlišuje a navzájem propojuje tři úrovně sociální reality: makroúroveň (societální podmínky, institucionální uspořádání), mezoúroveň (náboženští/sekulární kolektivní či skupinoví aktéři) a mikroúroveň (rodiny a jedinci). Sociologická vysvětlení vyplývající z této teorie míří na mezo- a makroúroveň (jednání kolektivních aktérů a agregované societální účinky), přičemž odkazují na agregovaná jednání individuálních a kolektivních aktérů (jedinci a organizace). Je přitom potřeba, aby byla uzpůsobena konkrétnímu charakteru jednotlivých prvků schématu - a tím abstraktní teoretický model transformovala do podoby teorie stredního dosahu v mertonovském smyslu (Stolz - Tanner 2017; srov. Hedström - Udehn 2009).

Pokud jde o potenciální slabá místa teorie nábožensko-sekulární konkurence, konstatuje Stolz, že nejvýznamnější vznesenou námitkou bylo podezření, že nejde o „nic jiného než o sekularizační teorii“ (Stolz - Tanner 2017: 317). S tím částečně souhlasí, když prohlašuje, že „stejně jako u sekularizační teorie si myslíme, že obecný trend směrem k technickým a societálním inovacím povede $\mathrm{z}$ dlouhodobější perspektivy k poklesu společenského zájmu o náboženství" (tamtéž). Na rozdíl od standardních sekularizačních teorií však teorie nábožensko-sekulární konkurence přináší trri důležitá vylepšení: 1) dává větší prostor jednajícím (individuálním i kolektivním) aktérům; 2) dokáže vysvětlit jak sekularizující, tak resakralizační tendence; 3) je aplikovatelná na různé úrovně sociální reality ${ }^{22}$.

\section{Kudy dál?}

Cílem této stati bylo kriticky zhodnotit dosavadní sociologické studium české religiozity s ohledem na jeho využití teorie jako nástroje pro formulování pod-

\footnotetext{
21 Ve věci rozlišení mezi náboženskými a sekulárnimi statky Stolz uvádí, že mezi nimi existují nejméně čtyři rozdíly, přičemž pouze první z nich představuje rozdíl nutný; zbývající rozdíly jsou záležitostí míry a v jednotlivých př́ípadech nemusejí být přítomny. Jedná se o vztaženost k transcendentnu, ideologické zasazení, vazbu na sociální skupinu a netržní charakter (Stolz - Tanner 2017: 309-311).

${ }^{22} \mathrm{~V}$ tomto bodě je třeba dodat, že v rámci tzv. sekularizační debaty (blíže viz Vido 2011) už sociologie náboženství disponuje příspěvky, které reflektují slabá místa, která u sekularizačních teorií identifikuje Stolz - k zapojení aktérů do vysvětlení sekularizačního procesu viz např. Fenn (1978); Chaves (1994) nebo Gorski 2003; k propojování různých úrovní sociální reality viz např. Dobbelaere (1981) nebo Chaves (1994).
} 
nětných výzkumných otázek a současně jako prostředku $\mathrm{k}$ vysvětleni př́slušného sledovaného sociálního jevu. Ve druhém kroku se pak snažila zprostředkovat teoreticky podložený výzkumný program, které může být do budoucna nápomocen při snaze o důkladnější vysvětlení aktuálně nízké míry tradiční (tj. církevní/institucionalizované) religiozity v české populaci.

Domnívám se, že výše uvedené řádky doložily ne zcela uspokojivý stav stávajícího bádání na poli české sociologie náboženství na třech vybraných reprezentativních monografiích, které přinášejí řadu zajímavých poznatků deskriptivního charakteru, stejně jako více či méně zdařilé pokusy o vysvětlení či interpretaci zjištěných faktů. Jejich společný jmenovatel však tvoří absence koherentního teoretického rámce, který by sociologické teorii zajistil důstojnější postavení. Omezenost a určitou povrchnost dosavadních sociologických výkladů české religiozity lze přičíst právě nedostatečné práci (a obeznámenosti) s teoretickou složkou sociologické disciplíny, jejímž zřetelným projevem je praxe „ad hoc“ využívání sociologických teorií a konceptů doprovázená tendencí k (teoreticky explicitně nezdůvodněné) „historizaci“ sociologického studia. Tímto konstatováním nemá být popřena skutečnost, že sledovaní autoři nabízejí množství relevantních a inspirativních vhledů, které porozumění fenoménu české „bezbožnosti“ napomáhají. Domnívám se však, že v tomto ohledu mohlo být $\mathrm{v}$ české sociologii náboženství vykonáno daleko více ${ }^{23}$.

Jako jednu z možných cest $\mathrm{k}$ redukci identifikovaných nedostatků nabízím zapojení perspektivy analytické sociologie. Jak jsem se snažil ukázat na prríkladu práce Jörga Stolze, vybízí tento přístup ke kladení otázek, které směřují k podání sociologického vysvětlení, jež odkrývá sociální mechanismy propojující mikrorovinu (individuální jednání) a makrorovinu (agregované sociální jevy), přičemž respektuje specifika jednotlivých historických a kulturních kontextů. Tím zaplňuje mezeru, která je v české sociologii náboženství velkou měrou přítomná - totiž přetrvávající existenci „black boxů“ ve výkladech zdrojů současné české non-religiozity, v nichž jsou skryty mechanismy, jež způsobují na jedné straně „odnábožeňštující dopad strukturálních faktorů na individuální aktéry, na straně druhé pak sekularizaci na makrostrukturální úrovni vlivem individuálního jednání společenských aktérů.

Volání po využití analytické sociologie ve studiu (české) religiozity přitom nutně neznamená volání po (dalším) vytěžování kvantitativních dat a (dalším) zapojování statisticko-analytických metod. Je nepochybné, že využití těchto dat a procedur je pro danou agendu prospěšné; a v tomto ohledu lze v úvodu zmiňovaný prrísun nového datového materiálu $\mathrm{z}$ výběrových šetření EVS a ISSP jenom uvítat. Tento fakt nicméně nevylučuje výraznější zapojení kvalitativních

\footnotetext{
23 Tento text programově reaguje na stav bádání v české sociologii náboženství. Tím však nemá být argumentace ve prospěch představeného př́stupu omezena pouze na tento dílčí národní kontext. „Český př́pad“ zde spiše plní funkci konkrétní ilustrace potřebnosti teorie při sociologickém studiu náboženství, resp. sekularizace.
} 
metod, resp. jejich důkladnější provázání s metodami kvantitativními - tedy to, po čem ve své přehledové studii volal Jan Váně (2012). Důkazem je ostatně v této stati představená práce Jörga Stolze (Stolz et al. 2016), která se opírá o oba typy dat $\mathrm{v}$ rámci výzkumného designu smíšených metod (mixed methods) $)^{24}$.

Roman Vido pưsobi na Katedře sociologie Filozofické fakulty Ostravské univerzity a současně jako vědecký pracovník v Sociologickém ústavu AV ČR v.v.i. Ve výzkumné práci se věnuje problematice náboženství v moderni společnosti, sekularizace a empirickým analýzám religiozity v české společnosti. Je autorem monografie Konec velkého vyprávění? Sekularizace v sociologické perspektivě (CDK, 2011).

\section{LITERATURA}

ABEND, G., 2008: The Meaning of „Theory“. Sociological Theory, roč. 26, č. 2, s. 173-199.

BOUDON, R., 2011: Ordinary Rationality: The Core of Analytical Sociology. In: Demeulenaere, P. (ed.): Analytical Sociology and Social Mechanisms. Cambridge: Cambridge University Press, s. 33-49.

CHAVES, M., 1994: Secularization as Declining Religious Authority. Social Forces, roč. 72, č. 3, s. 749-774.

COLEMAN, J. S., 1986: Social Theory, Social Research, and Theory of Action. The American Journal of Sociology, roč. 91, č. 6, s. 1309-1335.

DIVIÁK, T., 2018: Pojetí aktéra a jednání v analytické sociologii. In: Šubrt, J. - Německý, M. a kolektiv: Jedinec a společnost. Úvahy nad konceptem homo sociologicus. Praha: Sociologické nakladatelství.

DOBBELAERE, K., 1981: Secularization: A Multi-Dimensional Concept. Current Sociology, roč. 29 , č. 2, s. 1-213.

FENN, R. K., 1978: Toward a Theory of Secularization. Storrs: Society for the Scientific Study of Religion.

FROESE, P. - PFAFF, S., 2005: Explaining the Religious Anomaly: A Historical Analysis of Secularization in Eastern Germany. Journal for the Scientific Study of Religion, roč. 44, č. 4, s. 397-422.

GORSKI, P. S., 2003: Historicizing the Secularization Debate: An Agenda for Research. In: Dillon, M. (ed.). Handbook of the Sociology of Religion. Cambridge: Cambridge University Press, s. 110-122.

HAMPLOVÁ, D., 2000: Náboženství a nadpřirozeno ve společnosti. Mezinárodní srovnání na základě empirického výzkumu ISSP. Sociologické texty/Sociological Papers 00:03. Praha: Sociologický ústav AV ČR.

HAMPLOVÁ, D., 2001: Institucionalizované a neinstitucionalizované náboženství v českém poválečném vývoji. Soudobé dějiny, roč. 8, č. 2-3, s. 294-311.

HAMPLOVÁ, D., 2008: Čemu Češi věrí: dimenze soudobé české religiozity. Sociologický časopis/Czech Sociological Review, roč. 44, č. 4, s. 703-723.

HAMPLOVÁ, D., 2013: Náboženství v české společnosti na prahu 3. tisíciletí. Praha: Karolinum.

${ }^{24}$ K metodologické reflexi analytické sociologie a argumentaci pro využití smíšených metod v ní viz Stolz (2016). 
HAMPLOVÁ, D. - NEŠPOR, Z. R., 2009: Invisible Religion in a „Non-Believing“ Country: The Case of the Czech Republic. Social Compass, roč. 56, č. 4, s. 581-597.

HAMPLOVÁ, D. - ŘEHÁKOVÁ, B., 2009: Česká religiozita na počátku 3. tisíciletí. Praha: Sociologický ústav AV ČR.

HAVELKA, M., 2010: Ideje - Dějiny - Společnost. Studie k historické sociologii vědění. Brno: CDK.

HAVLÍČEK, J., 2016: Religious Memory and Transmission of Knowledge on Religions through Education. The Case of Education System in the Czech Republic. Pantheon, roč. 11, č. 1, s. 77-93.

HEDSTRÖM, P., 2005: Dissecting the Social. On the Principles of Analytical Sociology. Cambridge: Cambridge University Press.

HEDSTRÖM, P. - SWEDBERG, R. (eds.), 1998: Social Mechanisms: An Analytical Approach to Social Theory. Cambridge: Cambridge University Press.

HEDSTRÖM, P. - UDEHN, L., 2009: Analytical Sociology and Theories of the Middle Range. In: Hedström P.- Bearman P. (eds.): The Oxford Handbook of Analytical Sociology. Oxford: Oxford University Press, s. 25-47.

HEDSTRÖM, P. - YLIKOSKI, P., 2010: Causal Mechanisms in the Social Sciences. Annual Review of Sociology, roč. 36, s. 49-67.

IANNACCONE, L. R., 1992: Religious Markets and the Economics of Religion. Social Compass, roč. 39, č. 1, s. 123-131.

KRAUSE, M., 2016: The Meaning of Theorizing. The British Journal of Sociology, roč. 67, č. 1, S. 23-29.

KRETING, J. - SCHEEPERS, P. - VERMEER, P. - HERMANS, C., 2018: Why God Has Left the Netherlands: Explanations for the Decline of Institutional Christianity in the Netherlands Between 1966 and 2015. Journal for the Scientific Study of Religion, roč. 57, č. 1, s. 58-79.

KVASNIČKOVÁ, A., 2005: Náboženstvo jako kolektívna pamät: prípad Slovenska a Čiech. Bratislava: Univerzita Komenského v Bratislavě.

LUŽNÝ, D., 2010: Dana Hamplová, Blanka Řeháková: Česká religiozita na počátku 3. tisíciletí. Výsledky Mezinárodního programu sociálního výzkumu ISSP 2008 - Náboženství. Sociologický časopis/Czech Sociological Review, roč. 46, č. 5, s. 835-837.

LUŽNÝ, D., 2012: Vytváření sociologické teorie náboženství. Sociální studia, roč. 8, č. 1, s. 93118.

LUŽNÝ, D., 2015: Teorie racionální volby v současné sociologii náboženství. Sociológia, roč. 47 , č. 2, s. 151-170.

LUŽNÝ, D. - NAVRÁTILOVÁ, J., 2001: Religion and Secularisation in the Czech Republic. Czech Sociological Review, roč. 9, č. 1, s. 85-98.

LUŽNÝ, D. - NEŠPOR, Z. R. a kol., 2008: Náboženství v menšině. Religiozita a spiritualita v současné české společnosti. Praha: Malvern.

MacCOLMAN, L., 2015: The Central Arguments of Isaac Ariail Reed's Interpretation and Social Knowledge. Sociologický časopis/Czech Sociological Review, roč. 51, č. 3, s. 475486.

MANZO, G., 2010: Analytical Sociology and its Critics. European Journal of Sociology/Archives Européennes de Sociologie, roč. 51, č. 1, s. 129-170.

MIŠOVIČ, J., 2001: Víra v dějinách zemí Koruny české. Praha: Sociologické nakladatelství.

MOUZELIS, N., 1995: Sociological Theory: What Went Wrong? Diagnosis and Remedies. London: Routledge.

NEŠPOR, Z. R., 2004: Religious Processes in Contemporary Czech Society. Sociologický časopis/Czech Sociological Review, roč. 40, č. 3, s. 277-295.

NEŠPOR, Z. R., 2010: Př́liš slábi ve víře. Česká ne/religiozita v evropském kontextu. Praha: Kalich. 
NEŠPOROVÁ, O. - NEŠPOR, Z. R., 2009: Religion: An Unsolved Problem for the Modern Czech Nation. Sociologický časopis/Czech Sociological Review, roč. 45, č. 6, s. 1215-1237.

PABIAN, P., 2013: Alternativní př́běh české sekularity. Sociální studia, roč. 10, č. 3, s. 85-105.

PETRUSEK, M., 2011: Návrat (sociologické) teorie do Čech? Východiska, stav a perspektivy. Sociologický časopis/Czech Sociological Review, roč. 47, č. 5, s. 1017-1033.

REED, I. A., 2011: Interpretation and Social Knowledge. On the Use of Theory in the Human Sciences. Chicago: The University of Chicago Press.

SCHENK, J., 2014: Analytická sociológia: niekol'ko metodologických inšpirácií. Sociológia, roč. 46, č. 2, s. 130-145.

SCHENK, J., 2017: Explanačné modely v súčasnej analytickej sociológii. Bratislava: STIMUL.

SPOUSTA, J., 2002: Changes in Religious Values in the Czech Republic. Sociologický časopis/Czech Sociological Review, roč. 38, č. 3, s. 345-363.

STARK, R. - FINKE, R., 2000: Acts of Faith. Explaining the Human Side of Religion. Berkeley: University of California Press.

STOLZ, J., 2009a: Explaining Religiosity: Towards a Unified Theoretical Model. The British Journal of Sociology, roč. 60, č. 2, s. 345-376.

STOLZ, J., 2009b: Gods and Social Mechanisms. New Perspectives for an Explanatory Sociology of Religion. In: Cherkaoui, M. - Hamilton, P. (eds.): Raymond Boudon. A Life in Sociology. Essays in Honour of Raymond Boudon. Volume 3. Oxford: The Bardwell Press, s. $171-188$.

STOLZ, J., 2016: Opening the Black Box. How the Study of Social Mechanisms Can Benefit from the Use of Explanatory Mixed Methods. Analyze \& Kritik, roč. 38, č. 1, s. 257-286.

STOLZ, J. - KÖNEMANN, J. - SCHNEUWLY PURDIE, M. - ENGLBERGER, T. KRÜGGELER, T., 2016: (Un)Believing in Modern Society. Religion, Spirituality, and Religious-Secular Competition. New York: Routledge.

STOLZ, J. - TANNER, P., 2017: Elements of a Theory of Religious-Secular Competition. Política \& Sociedade, roč. 36, s. 295-323.

SWEDBERG, R., 2016: Before Theory Comes Theorizing or how to Make Social Science More Interesting. The British Journal of Sociology, roč. 67, č. 1, s. 5-22.

TÍŽIK, M. 2011: Náboženstvo vo verejnom živote na Slovensku. Zápasy o ideový charakter štátu a spoločnosti. Bratislava: Sociologický ústav SAV.

VÁCLAVÍK, D., 2010: Náboženství a moderní česká společnost. Praha: Grada.

VÁCLAVÍK, D., 2014: Deepening Secularization? How to Read Official Statistics. A Case of the Czech Republic. Diskus, roč. 16, č. 2, s. 22-30.

VÁCLAVÍKOVÁ HELŠUSOVÁ, L. - VÁCLAVÍK, D., 2006: Institucionalizovaná forma religiozity a její projevy v České republice v letech 1989 až 2000. Religio. Revue pro religionistiku, roč. 14 , č. 2 , s. 45-64.

VÁNĚ, J., 2012: Výzkumy věnující se podobám religiozity v České republice po roce 1989. In Krejčí, J. - Leontiyeva, Y. (eds.): Cesty k datům. Zdroje a management socialněvědních dat v České republice. Praha: Sociologické nakladatelství, s. 355-398.

VÁNĚ, J. - ŠTÍPKOVÁ, M., 2013: The National Religious Environment and the Orthodoxy of Christian Beliefs: A Comparison of Austria, the Czech Republic and Slovakia. Sociologický časopis/Czech Sociological Review, roč. 49, č. 3, s. 403-426.

VIDO, R., 2011: Konec velkého vyprávění, sekularizace v sociologické perspektivě. Brno: CDK.

VIDO, R., 2016: Možnosti konceptu paměti pro sociologické studium náboženství v české společnosti. In: Laiferová, E., Mistríková, L'. (eds.): Dvadsat'pät' rokov sociologickej rozmanitosti. Siedme slovensko-české sociologické dni. Zborník príspevkov z medzinárodnej vedeckej konferencie. 28. 5. 2015, Bratislava. Bratislava: Univerzita Komenského, s. 143-173. 